\title{
Erindring i Det Gamle Testamente
}

\author{
Lektor Ph.d \\ Pernille Carstens
}

\begin{abstract}
Literary texts are paths or tracks into cultural memory, not direct access to unmediated memory. Cultural memory studies are about how the past is mediated, how memory is produced and circulated. It is not about history "as such". The Old Testament was created in periods of globalization. The writing is a piece of memory work meant for creation of national or local identity, and particularity in a global world. Memory as counter-activity is always present, focusing on the local, small tradition, the particular narrative, and creating its own way of coherence. Memories are not ready-prepared reflections of the past. They are both eclectic and selective reconstructions. Remembering and forgetting the past reflects the needs in the present. It is an active and ongoing, not predetermined process. Memory studies do not represent a coherent field, but are coming from different disciplines and discursive areas. It is an analytic instrument and a heuristic tool focusing the socio-cultural context.
\end{abstract}

Keywords: Cultural memory - process - globalization - local identity remembering - forgetting - cultural heritage - context -index

Gammel Testamente er en del af vores kulturarv, og den er vi forpligtet på at bevare, forstå og fortolke som en del af vores egen tradition. Mennesket er aldrig alene, men er altid relateret til grupper som familien, et sted, en uddannelse, en arbejdsplads og en profession. Mennesket bor i områder og er knyttet til det bestemte land og den bestemte by. Det tilhører religiøse retninger, politiske partier osv. og får sine forståelsesrammer ud fra disse kollektiver. Det er denne menneskelige kontekst, som hukommelsen, eller erindringen, skal ses ud fra. ${ }^{1}$ Gammel Testamente er et eksempel på, hvordan et antikt samfund erindrer og glemmer, og læsningen af Gammel Testamente giver os et bud på, hvordan man har set på fortiden, omtalt og benyttet den strategisk og politisk. Der er anvendt mange litterære genrer i Gammel Testamente, og mange af disse er sammenlignelige med andre kulturelle udtryk. Det kan være inden for tekstsamlingen selv, blandt

1. For en diskussion af den kollektive erindring: Jeffrey K. Olick, Vered VinitzkySeroussi and Daniel Levy, The Collective Memory Reader (Oxford: Oxford University Press 2011). 
materielle udtryk fra Palæstina og andre kilder fra omkringliggende samfund og kulturer. For selvom tekster og genstande, landskaber og monumenter ofte kun fremstår som fragmenter og ruiner, så er de aftryk af fortiden.

Gammel Testamente er blevet til i en periode, der er præget af globalisering, og det virker, som om Det Gamle Testamente er stykker af tilrettelagt erindringslitteratur, som man har anvendt i forsøget på at skabe national identitet og særtræk. Modvægten mod globaliseringen kan være at fokusere på den lille lokale tradition, på den egne stemme, der skaber sammenhæng i selvforståelsen.

Begrebet "kulturel erindring" finder man anvendt både inden for humanvidenskaberne og samfundsvidenskaberne. Kulturel erindring kan fremtræde som overskrivning og genbrug, som det fx gælder for bygninger og monumenter og andre materielle genstande, samt tekster og rituel praksis. Erindring kan være bevidst eller ubevidst, indlejret i kroppen og vise sig i kulturen. Når man undersøger disse elementer i Gammel Testamente, må man sætte Gammel Testamente ind i sin kulturelle kontekst og opfatte teksterne der på linje med andre kulturelle udtryk. Erindringsstudier repræsenterer ikke et kohærent felt, det er et analytisk instrument og et heuristisk redskab til at kunne fokusere på den sociale og kulturelle kontekst. ${ }^{2}$

\section{At huske og erindre}

I den nordiske mytologi findes forestillingen om guden Odins alvidenhed. Han opsøger Mimer ved brønden for at kunne få råd eller skue ind i andre dimensioner. Mimir betyder formentlig "den der kan erindre." Odin har også to ravne, Hugin og Munin. Navnene betyder henholdsvis "tanke" og "erindring" og opfattes ligesom Mimer som personifikationer af egenskaber hos Odin. Ravnene sendes ud om morgenen og kommer hjem ved aftenstide og fortæller guden om, hvad de har set og hørt. ${ }^{3}$

I den mesopotamiske kultur kender man til visdomsguden Eas dobbelthovede minister Usmû eller Isimud. Ea er den mesopotamiske vand- og visdomsgud, som er forbundet med magi og besværgelser, med kunst og håndværk. Navnet Usmû betyder muligvis "med to ansigter", og ikonografisk findes han afbilledet sådan. Usmû skal rapportere til Ea, hvad han ser og hører: Det ene ansigt skuer tilbage i

2. Astrid Erll and Ansgard Nünning, A Companion to Cultural Memory Studies (Berlin, New York: de Gruyter 2010), 4.

3. Finn Stefánsson, Gyldendals Leksikon om Nordisk Mytologi (København: Gyldendal 2005), $154 \mathrm{f}$. 
fortiden, det andet ser ind i fremtiden. Dermed minder han om andre tohovede guder, vi kender fra romersk religion, hvor fx Janus er guddom for byporten. Han afbildes som en herme med to ansigter, der skuer frem og tilbage. ${ }^{4}$

Hos profeten Esajas hedder det i kap. 49 om Jahve, at han husker ligesom en mor. Når Jerusalem jamrer og siger, at Jahve har svigtet og glemt byen, siger Esajas: "Glemmer en kvinde sit diende barn? Glemmer en mor det barn, hun fødte? Selv om de skulle glemme, glemmer jeg ikke dig." Og derfor er det også, at Jahve kan sige om sig selv i kap. 46,9-10: "Husk hvad der skete tidligere, for længe siden! For jeg er Gud, der er ingen som jeg. Fra begyndelsen har jeg forkyndt fremtiden, i fortiden det, der endnu ikke var sket." Det udsagn kunne være i munden på en vølve, og i teksten knyttes indsigten om verdens gang og erindringen sammen. $\mathrm{Nu}$ er det afgørende jo ikke, hvor eksplicit Gammel Testamente udtrykker en aktiv brug af erindring, fortid og fremtid, man må jo helt generelt fare med lempe med hensyn til generalisering af en bestemt opfattelse i tekstgrupper så forskelligartede som i Det Gamle Testamente, men erindringen er undersøgelsesfelt for nærværende artikel.

Forfatteren til Esajasteksten har kendskab til, at erindring holdes i live for at lade fortiden blive en aktiv del af nutiden, fordi fortiden er med til at skabe forudsætningerne for, hvordan nutiden leves og forstås. Hvis der ingen fortid er, så er der heller intet håb for fremtiden. Det er ikke bare en erfaring, Gammel Testamente gør sig, det er en almen menneskelig konstatering, som også tematiseres i psykologien. Hvis man ikke kan huske sin fortid, er det vanskeligt at leve uafhængigt af den, og man vil heller ikke have muligheder for at forestille sig fremtiden eller knytte håb til den. ${ }^{5}$ Et af principperne for Michael Whites terapi for traumeofre er at genudvikle og revitalisere "fornemmelsen af mig selv". Dette kan opnås gennem anvendelse af definerede ceremoni-strukturer, som kan have funktion af katarsis (White 2008,49f.), eller ved genfortællinger, der er eksternt bevidnede, og ved genforfattede samtaler. White henviser til resultater hos hukommelsesteoretikere, der arbejder med flere forskellige hukommelsessy-

4. Se Pernille Carstens, "Old Testament as the Art of Remembering: Landscape as Paidaia", Cultural Memory in Biblical Exegesis, red. P. Carstens, T. Hasselbalch and N.P. Lemche (Gorgias Press 2012), 13-31.

5. Michael White, Maps of Narrative Practice (New York London: W.W. Norton and Company 2007). Michael White, "At arbejde med mennesker, som lider under konsekvenserne af multiple traumer. Et narrativt perspektiv." Traumer, Narrativ behandling af traumatiske oplevelser, red. David Denborough (Dansk Psykologisk Forlag 2008), 39-93. 
stemer, deriblandt det Meares kalder "stream of consciousness". ${ }^{6}$ Det, der sker ved traumatiseringen, er, at flere af de erindringsmæssige systemer nedbrydes, det gælder den selvbiografiske hukommelse og den episodiske (White 2008, 84). Hverdagsbevidstheden er frakoblet, og der er ikke længere det, som White kalder et udsigtspunkt i nutiden. Det lader sig heller ikke forene med en egentlig narrativ (White $2008,85)$. Udover at det nedbryder det ramte menneskes selvværd, så er disse halve erindringer ikke mulige at bygge narrativer op på, det bliver til en krønike $\mathrm{i}$ stedet for en egentlig sammenhængende fortælling (White 2008, 86). Det er målet med Whites strategi at få reetableret en sikkerhed for traumeofrene, og det sker ved at skabe kontekst for en personlig egen og stærk fortælling, der er bygget op omkring de bærende værdier i det ramte menneskes liv. Det er at fornemme sig selv og kunne forbinde selv dissocierede erindringer (White 2008, 91).

Tentativt vil jeg i forlængelse af disse observationer foreslå, at man forsøger at anskue dele af Det Gamle Testamente som sådan en bevidst tilrettelagt kontekst, inden for hvilken mennesker kan skabe sig eller finde et håb, og genskrive sin egen narrativ i en national fortælling om skabelse, bortsendelse, vandring, exodus, eksil og håb om et land og et folk. Det svarer godt overens med den observation, jeg har gjort, at længslen kan forstås som et gennemgående tema i visse dele af Gammel Testamente, og da især knyttet til den tempelorienterede teologi. ${ }^{7}$ Alt i alt er disse strategier udtryk for, hvad man kunne kalde orienteringsstrategier, som bygger på den generelle tendens til et "mobility turn" i den humanistiske forskning. Det er en måde at udtrykke identitet og egenart på, som også kan komme til udtryk i en egentlig teologi. ${ }^{8}$

6. R. Meares, Intimacy and Alienation: Memory, trauma and personal being (London: Routledge 2000).

7. Pernille Carstens, "The Golden Vessels and the Song to God." Scandinavian Journal of the Old Testament 17, 2003, 110-140. Pernille Carstens, "Mellem tavshed og sang", Dansk Teologisk Tidsskrift 64, 2001, 97-111. Pernille Carstens, "Seeing and Seeking God in his Temple. The Theology of the Dwelling God, GIS.HUR gul-za-at-ta-ra. Festschrift for Folke Josephson, Meijerbergs Arkiv för ordforskning red. Gerd Carling (Göteborg 2006), 46-59.

8. Det viser sig tydeligst hos John Urry i Mobility, Cambridge 2007, hos Tim Cresswell, On the move. Mobility in the modern Western World (Routledge 2006 ) og Peter Adey, Mobility (Routledge 2010). 


\section{Loven skal huskes}

En stor del af Gammel Testamente kan forstås som en lang samlet fortælling om folkets tilblivelse og retten til at bebo Palæstina. Man kan forstå teksterne fra Første Mosebog og til udgangen af anden Kongebog som et slags epos. Det er ikke afgørende, om denne fortælling udtrykker historisk sandhed. Det afgørende er at forstå dens betydning. Man ville jo heller aldrig spørge, om det virkelig var sandt, at Odysseus var 10 år om at vende hjem, eller om hans mænd virkelig blev tryllet om til grise på troldskvinden Kirkes $\varnothing$ på vej hjem fra Troja. Da loven bliver givet israelitterne på vandringen $\mathrm{i} ø r k e n e n$, fortælles det i Deut. 6, at israelitterne skal gentage loven og gentage trosbekendelsen: "Hør Israel, Herren vor gud, Herren er én". Fædrene skal gentage dette udsagn for sønnerne, det skal siges hjemme og ude, morgen og aften, så gentagelsen gør det nemmere at huske. Ud over at repetere skal loven og bekendelsen også være synlig på kroppen: De skal bindes om hånden, og de skal sidde på panden, og ved huset skal man sætte loven synligt op ved dørstolperne, og i byen i portene. Disse fysiske tegn skal hindre glemsel. Glemslen vil betyde ligegyldighed over for den guddom, der har befriet israelitterne fra Ægypten og lovet dem et nyt land. Når du har spist dig mæt, siger teksten i v. 11, skal du passe på, at du ikke glemmer, hvem der førte dig ud af Ægypten. At glemme vil blive straffet med døden, sådan som det fremgår af listerne over forbandelser, der kan ramme en ved lovbrud i Deut. kap. 28.

\section{At skrive det ned}

Når loven sidder på håndleddet eller i panden, er det et fysisk udtryk for erindring, det er til at tage og føle på, og det kan ses. En anden måde at huske på er at skrive tingene ned. I Deut. 27 fortælles det med en episode. Den udspiller sig, inden israelitterne går over Jordan til det land, Gud har lovet dem. Moses befaler folket at opstille nogle store sten og stryge dem med kalk. Når folket så er kommet ind $\mathrm{i}$ landet, skal man skrive loven på stenene, der så skal opstilles på Ebals bjerg. "På stenene skal du skrive alle ordene i denne lov med tydelig skrift" (v.8).

Der findes flere beskrivelser af den fysiske tilstedeværelse af erindringen. I Josvabogen kap. 4 beskrives den tilsvarende episode, da israelitterne er kommet over Jordan og skal til at erobre landet. Her skal en fra hver af de tolv stammer tage en sten, og de skal så opstilles, og når sønnerne så i fremtiden spørger, hvad det er for sten, skal der 
svares: "Vandet i Jordan forsvandt foran Herrens pagts ark; dengang den gik over Jordan, forsvandt vandet i Jordan. Disse sten skal for israelitterne være mindesten til evig tid."

I det hele taget findes der i Gammel Testamente flere eksempler på, at der laves huskelister for at erindre fortiden, gemme den og lade den leve videre. ${ }^{10}$ Sådan kan man se på den næsten endeløse række af offerlister eller fortegnelse over tempelinventar, som vi finder i Exodus til og med Numeri. Her findes bl.a. beskrivelsen af åbenbaringsteltet. Hver eneste teltdug er nævnt, farverne, materialet og målene på dem, længden på plankerne. Der er forordninger for præstedragterne (Ex 28) og opbygningen af den mobile telthelligdom, med anvisninger for etableringen af helligdommen og dens inventar. Denne detaljerigdom skal sikre nøjagtighed, sådan at Jahve kan tage bolig i helligdommen (Ex 25,8f. og 40,34f.). Men når det opregnes så møjsommeligt, har det jo også karakter af en huskeliste. Tempellister af denne type er kendt i andre Middelhavskulturer og er en del af erindringsarbejdet, kan man sige. ${ }^{11}$ Teksterne i Mosebøgerne tegner et billede af fortiden, som man fastholder og har samlet senere i historien. Én af grundene til, at dette sker, er at sikre israelitternes ret til landet og til at påstå en kontinuerlig historie fra skabelsens dage til en aktuel situation som $\mathrm{fx}$ et fangeskab i Babylon eller et fremmed herredømme som i

9. zikkaron oversættes med mindesten og betyder "erindring”. Jf. samme betydning i skildringen af fyrbækkenerne i Num 17,5, der bliver udhamret til mindeplader på alteret; dvs. en meget fysisk håndtering og forståelse af erindringen. Verbet zakar betyder "at mindes", "at huske", "at tænke". Woudstra skriver i sin kommentar om stedet i Josva således: "The notion of remembering in Hebrew is more than a calling to mind. It involves a remembering with concern". Marten H. Woudstra, The Book of Joshua.The New International Commentary on the Old Testament (William B. Eerdmans Publishing Company, Grand Rapids. Michigan 1982), 92.

10. Paul Connerton, "Seven types of forgetting", Memory Studies 1, 2008, 59-71 og Aleida Assmann, "Canon and Archive", Olick 2011, 334-337. Med hensyn til tempellisterne har jeg andetsteds påpeget dette som en specifik form for erindringsbevarelse, som jeg kalder arkivering. Pernille Carstens, "The Torah as Canon of Masterpieces: Remembering in Archives", Cultural Memory in Biblical Exegesis, red. P. Carstens, T. Hasselbalch og N.P. Lemche (Gorgias Press 2012), 309-327. Det er indlysende, at netop det at gemme fortiden spiller en afgørende rolle i den imperiale kulturs arkiver i antikken - denne viden er med til at skabe institutioner (Connorton 2008, 65). Arkiverne står bag om ideen om biblioteker og kunstsamlinger og bag ideen om museet. Både arkiverne, kunstsamlingerne og museerne bevarer kultur og danner registre og indeks. Connertons pointe er, at denne særegne måde at gemme på også findes i nutidige samfund - nu taler man om arkiver med anvendelse af den nye informationsteknologi som computere $\mathrm{fx}$ - men der er tale om den samme basis: Dette er en måde at kontrollere information på som et politisk redskab.

11. Et oplagt eksempel på dette findes i Lindoskrøniken, Carolyn Higbie, The Lindian Chronicle and the Greek Creation of their Past (Oxford: Oxford University Press 2005). 
hellenistisk tid. Helligdomme og hellige genstande er altid mål som krigsbytte, det er det, babylonerkongen Nebukadnesar tager med sig fra Jerusalem som krigsbytte, fordi national identitet og egenart er knyttet dertil (2 Kong 25). Den israelitiske gud Jahve er en nationalgud, og hans tempel med alt inventar er udtryk for hans storhed og for hans beskyttelse af sit folk. Det er Jahve, der har besluttet sig for at bo blandt israelitterne i sit tempel.

I Gammel Testamente findes flere udtryk for disse former for lister. Slægtstavler er også gode eksempler derpå. I Deuteronomium opregnes Adams slægt fra Adam til Noa, hvor faderen og dennes søn nævnes og alderen. "Da Adam havde levet 130 år, fik han en søn, der lignede ham og var et billede af ham. Ham kaldte han Set. Efter Adam havde fået Set, levede han i 800 år og fik sønner og døtre. Adam levede i 930 år, så døde han.” Kap. 10 i samme bog er også sådan en slægtstavle, dvs. en systematiseret måde at huske på.

Det at skrive noget ned aktivt omtales ikke så mange gange i Gammel Testamente. Num 33 er et af de få eksempler på dette, og her er det også sammen med en form for huskeliste. I dette kapitel i Numeri finder vi i listeform en fortegnelse over alle de steder, israelitterne var under de 40 års ørkenvandring. Det er en huskeliste over vandringerne fra sted til sted, fra den dag de bryder op fra Ægypten efter påske, til den dag de kommer ind i det lovede land. Det er på Jahves befaling, at Moses skal skrive ruten ned, og det er, fordi denne liste er en milepæl i folkets egen historie. Denne rejserute gennem ørkenen bliver en af de mest formative perioder i folkets selvforståelse, på vej fra trældom i Ægypten til forløsning i det eget land. Overgangen udspiller sig på rejsen på vej mod målet. Det ved forfatterne bag Numeri, og detaljerigdommen her tjener det samme formål: At lade fortiden stå så klart i erindringen som muligt. Tempellisterne, arkiverne og kunstsamlingerne gør det samme, nemlig at skabe en kollektiv erindring om fortiden som en politisk strategi. Toraen er som paideia, uddannelse. Toraen er den gode smag, en kanon af masterpieces, der refererer til fortiden. ${ }^{12}$

\section{Monumenter}

Markering i landskabet findes også omtalt i Gammel Testamente. I Gen 28, da Jakob er på vej til sin morbror i Mesopotamien, overnatter han i byen Betel. Han møder Gud i en drøm, og som tak for den velsignelse, der bliver lyst over Jakob, rejser han en stele på stedet.

12. Carstens 2012, 13-31 og Pernille Carstens, "Jonas bog som læring", Dansk Teologisk Tidsskrift 70 (2007), 11-24. 
Den opretstående sten dyrker Jakob ved at hælde olie over den, og han lover, at hvis hans rejse lykkes, så vil han dyrke stenen som en helligdom og betale tiende. Stelen, som Jakob rejser, er en erindring om Gud velsignelse af Jakob.

I kap. 35 i Genesis fortælles der om Jakobs hustru Rakel. Hun er gravid og står over for en hård fødsel. Hun ønsker sig brændende en dreng og får Benjamin, men dør i barselsengen, og der står at læse (v. 19): "Da Rakel var død, blev hun begravet ved vejen til Efrat, det samme som Betlehem. Jakob rejste en stenstøtte på hendes grav. Det er Rakels gravstøtte, som står der den dag i dag."

Det samme beskrives i 2 Sam 18,18, hvor det fortælles, at mens Absalom var i live, havde han rejst en stenstøtte, som står i Kongedalen. Absalom begrunder opstillingen med: "Jeg har ingen søn til at bevare mindet om mig." Absalom opkalder stenstøtten efter sig, og teksten siger, at stedet den dag i dag kaldes Absaloms Minde. ${ }^{13}$

\section{Kroppen}

Der er også eksempler på, hvordan kroppen indgår i erindringsbearbejdelsen i Gammel Testamente. Vi har set på eksemplet om loven, der skal være knyttet til kroppen, sat på pande og håndled. Da den første påske beskrives i Exodus, er fortællingen fokuseret på kroppen. Denne fortælling har en funktion for en videre opdragelse, som det fremgår af kap. 12,25f., hvor det siges, at når israelitterne kommer ind $\mathrm{i}$ det lovede land, så skal påskeskikken overholdes, og når børnene spørger, hvorfor man gennemfører disse sære skikke, så skal der svares, at det var, fordi Jahve beskyttede folket påskenat og lod døden ramme ægypterne. Påskeofferet skal slagtes hjemme påskeaften, i modsætning til alle andre ofre, der bringes ved helligdommen og slagtes der. Blodet fra dyret skal anvendes til at smøre på dørstolper og overliggeren, men ellers skal kødet anvendes til et måltid hjemme. Kødet skal mod al sædvane steges og spises med det samme, sammen med urter og usyret brød. Men det skal indtages på en bestemt måde: Kjortelen skal bindes op om lænderne, og man skal have sandaler på fødderne og en stav i hånden. Det hele skal gå hurtigt. Det er den påske, der skal huskes og mindes og fejres igen og igen. Det er en begivenhed, som er relateret til kroppen og tæt forbundet med folkets udfrielse fra Ægypten bevaret og gemt i loven i Gammel Testamente.

Kroppen henvises der også til i forbindelse med andre ritualer. Et eksempel kunne være den store forsoningsdag, som den omtales i Lev

13. Igen zakar. 
16. Her gennemføres to typer ritualer. Det ene omhandler rengøringen af helligdommen. Det andet handler om at indkapsle urenhed ved at sende det med en buk ud i ørkenen. Alt dette gennemføres af kultisk personale. Men der findes i slutningen af ritualet en omtale af, hvordan dette bliver israelitternes lov. De skal på samme dag om efteråret føje sig til ritualet ved at spæge legemet, ved ikke at arbejde. Reglen gælder for alle, også de fremmede. Den dag skal der sones og renses, og der skal være fuldstændig hvile (v. 32).

I Num 5 findes et andet ritual beskrevet, som handler om loven om skinsyge eller jalousioffer. ${ }^{14}$ Hvis en kvinde har været sin mand utro, uden sin mands vidende, og er blevet uren, men der ingen vidner er, da skal den jaloux ægtemand bringe sin hustru til helligdommen. Med hende tager han et erindringsoffer, ${ }^{15}$ som usædvanligt består af bygmel, uden olie og uden røgelse (i modsætning til et almindeligt minha-offer skildret i Lev 2). Præsten skal stille kvinden i nærheden af helligdommen og tage helligt vand i en skål, hvori kan kommer noget af støvet fra gulvet. Kvinden skal stå med udslået hår og melofferet i hænderne, og præsten blander støv i dette vand, som teksten kalder bitterhedens vand. Er kvinden blevet uren, men ikke gravid, kan hun drikke vandet uden problemer. Men er der derimod sket en skade, så vil vandet forvolde hende forbandelser. Præsten skal skrive (katab) forbandelserne ned på et dokument (sefer $)^{16}$ og vaske ordene ud i vandet, og derpå skal han give hende dette bitre vand at drikke. Melofferet, som hun bærer på, skal svinges foran det allerhelligste og derpå bringes ud på alteret i forgården. Om kvinden er uren, vil hun rammes af forbandelser og smerter på kroppen og på denne måde bære sin straf. Ordene er opløst i vandet, som kvinden drikker, og hendes krop reagerer på. ${ }^{17}$

14. På hebraisk minha qenaot, jalousioffer, Jacob Milgrom, The JPS Torah Commentary Numbers (The Jewish Publication Society, Philadelphia, New York 1990), 39.

15. Zikkaron, som betyder erindring, er ikke blot ment som en mental akt, men har funktionen at karrikere eller hænge ud, se Baruch A. Levine, Numbers 1-20, A. New Translation with introduction and commentary, The Anchor Bible (Doubleday: New York og London 1993), 195. Den samme betydning påakkadisk zakāru(m), Jeremy Black, Andrew George og Nicholas Postgate, A Concise Dictionary of Akkadian (Wiesbaden Harrasowitz Verlag 2000), 443. Milgrom 1990, 39 siger, at i "a meal offering of remembrance which recalls wrongdoing" er den sidste del en tilføjelse, da erindringsofre ellers normalt opfattes som "the benefit of the offerer", jf. Ex 28,12. Se også Adriana Leveen, Memory and Tradition in the Book of Numbers, (Cambridge: Cambridge University Press 2008), 207.

16. Levine 1993, 183, 198, foreslår: med blæk, skrevet på pergament eller skind.

17. Skriften har en magisk funktion, og denne sympatetiske måde at opfatte magi på finder man i forbindelse med de såkaldte magiske skåle fra det aramæiske område især. Disse skåle er fra 7. årh. e.Kr. og beskrives hos J. B. Segal, Catalogue of 


\section{Iscenesættelse - bevidst brug af erindring}

I det følgende henviser jeg måske noget overraskende til et eksempel på dansk kulturarv, men det er et meget illustrativt eksempel på, hvordan erindringen kan indgå aktivt i forståelsen af kulturen. Det første eksempel stammer fra Sjælland ved Jægerspris slot. Udenfor slotshegnet ved vejen mod Kulhuse udgravede arveprins Frederik i 1776 Monseshøj, en jættestue. Den stammede fra bondestenalderen. Udgravningen blev publiceret af professor Ove Høegh-Guldberg. Han var historiker og teolog og arveprinsens lærer, som sikrede en dansk opdragelse efter Struenses fald. Guldberg betonede den nordiske fortid og arkæologien..$^{18}$ Efter udgravningen lod arveprins Frederik højen udsmykke af billedhuggeren Johannes Wiedewelt til et mindesmærke over sin mor dronning Juliane-Marie og som et politisk monument, deraf navnet Julianehøj. ${ }^{19}$ På højen blev der opsat syv ens runde mindestøtter af marmor, bærende navnene på tidligere hedenske Konger: Skjold, Frode Fredegod, Dan Mykillati, Harald Blåtand, Harald Haarfager, Gorm den Gamle og Wittekind. Den blev også beplantet med træer og hække, sådan at der nu var tale om et romantisk parkanlæg. I 1782 tilføjedes endnu en sten, en original norsk runesten, fundet 1781 i en gravhøj ved gården "Stenstad" i Telemarken, dateret til 4-500 e.Kr. Denne iscenesættelse taler næsten sit eget monumentale sprog; den oprindelige jættestue er ikke blot udgravet, men iscenesat og indsat $i$ et spind af fortid, som sagnkongerne trods alt må siges at være.

Men referencen til Frode Fredegod eller Skjold siger for det første noget om Frederiks eget syn på sin position i kongerækken - og det kan han jo behørigt takke sin mor for ved at få mindesmærket opført, men samtidigt har han altså aner tilbage. Originalitetskravet opfyldes ved opsættelsen af den ægte runesten fra Stenstad, og Wiedewelt indrammede dette i skabelsen af et romantisk haveanlæg. ${ }^{20}$ Set udefra i

the Aramaic and Mandaic Incantation Bowls at the British Museum, (London: The British Museum Press 2000).

18. Hakon Lund, Mindelunden ved Jagerspris ( Kong Frederik den Syvendes stiftelse på Jægerpris 1976), 12. Karen Kryger, "Julianehøj and the Memorial Grove at Jægerspris: An Introduction to the Interpretation of Julianehøj and the Nordic Monuments to Worthy Danes", The Rediscovery of Antiquity. Acta Hyperborea 10, red. Jane Fejer, Tobias Fischer-Hansen og Annette Rathje (København: Museum Tusculanum 2003), 235-254.

19. Marjatta Nielsen og Annette Rathje, Johannes Wiedewelt. A Danish Artist in search of the Past, Shaping the Future (København: Museum Tusculanum 2010).

20. Johannes Wiedewelt var en dansk billedhugger (1731-1802), som under et studieophold i Rom knyttede sig til nyklassicismens teoretiker Winckelmann. Wiedewelt publicerede i 1762 skriftet Tanker om Smagen udi Kunsterne i Almindelighed, der bygger på Winckelmanns syn på antikken. Winckelmann (1717-1768) var 
dag forstår man måske ikke umiddelbart, at der er tale om en form for palimpsest, en genskrivning i det monumentale. Men jættestuen er genbrugt og overskrevet med opstilling af mindestenene og overskrevet ved som samlet monument at indgå $\mathrm{i}$ et større politisk og lærdomsmæssigt projekt. ${ }^{21}$ Den gamle jættestue lever videre i dag og er under kulturarvsstyrelsen. ${ }^{22}$

Julianehøj er en del af et større didaktisk projekt, fordi der samtidig med højen opførtes en mindelund i parken og den tilstødende skov. Mindeparken er både tænkt pædagogisk og politisk (Lund 1976, 24) og indgår $\mathrm{i}$ et program for opstilling af mindesmærker over kendte personer i en dansk, norsk og holstensk sammenhæng og trækker her på viden fra Ove Mallings Store og gode Handlinger fra 1777. Om programmet i haven siger den tyske havekunstteoretiker Hirschfeld, at man føler sig hensat til Grækenlands hellige lunde (Lund 1976, 26). Han refererer til de elysæiske marker i Stowe ved Buckingham i England med de gamle dyders tempel, hvor der var givet plads til berømte udødelige englændere som Shakespeare, Newton, John Milton osv. Anlægget i Stowe stod færdigt i 1750.

I Ledreborg fandtes et tilsvarende program for et historisk-genealogisk-peripatetisk Akademi, som blev til i løbet af 1750'erne og stod klar 1763 på grev Holsteins tid (Lund 1976, 28), og var placeret $i$ slottets dyrehave, men der er i dag kun få rester tilbage af dette anlæg. Det var også et pædagogisk projekt, hvor man i havens lange gange, som fik navn efter nationer, opstillede omkring 400 monumenter over mennesker med fyrstelig herkomst. Der var enkle helfigursstatuer, som Knud den Hellige, obelisker som den over Harald Blåtand, marksten osv. og sirligt anlagte gangsystemer. Både i Jægerpris og i

grundlæggeren af den videnskabelige arkæologi og indførte stilkategoriseringen, præcis som det i eksegesen kendes hos Julius Wellhausen. Hans hovedværk Geschichte der Kunst des Alterthums fra 1764 er en kronologisk gennemgang af hele oldtidens kunsthistorie.

21. Marjatta Nielsen, "For King and Country", i: Nielsen og Rathje 2010, 85-111. 22. http://www.kulturarv.dk/fortidsminder/oplev-i-landskabet/monumenter-ilandskabet/storstensgrave/besoeg-gravene/julianehoej/Susan. E. Alcock, Archaeologies of the Greek Past, Landscape, Monuments, and Memories (Cambridge: Cambridge University Press 2002), 4. Ruth M. van Dyke and Susan E. Alcock, Archaeologies of Memory (Oxford: Blackwell 2003), 1. Manuela Günter definerer palimpsest således: "In kulturtheoretischer Perspective fungiert Palimpsest als Spur einer verborgenene Narration, in der sich das Verhältnis von Marginaliserung und Hegemonie, Anonymität und Autorisering als eines der Überlieferung fassen lässt - Schliesslich transportiert im Palimpeste der manifeste Text selbst seinen Subtext, sodass die Erinnerung an das von der Geschichte Verdrängte gerade im Medium seines scheinbaren Vergessens möglich wird“. Gedächtnis und Erinnerung. Ein interdisziplinäres Lexikon, red. Nicolas Pethes og Jens Ruchatz, (Hamburg: Rowohlt Taschenbuch Verlag GmbH 2001), $434 f$. 
Ledreborg er der tilknytning til oldtiden. Det er hvad Hakon Lund kalder "lærdom i det grønne", og hvad anlægget i Ledreborg angår, er det nærliggende Lejres nationalhistoriske betydning ikke til at overse; her hvor de ældre danske konger residerede. ${ }^{23}$ Pointen med disse anlæg er at vandre og gå sig til indsigt som de græske vandrefilosoffer, peripatetikerne, og de skildrede anlæg har da også et fokus på lærdom og erindring af fortiden. Anlæggene har et heuristisk ærinde og sammenkæder det med forestillingen om "vejen til indsigt". ${ }^{24}$

\section{Indeks og erindring}

Designeren Christien Meindertsma har brugt tre år på at undersøge alle de produkter, der bliver lavet af svin. Der var overraskende resultater: Ammunition, medicin, fotopapir, hjerteventiler, bremser, tyggegummi, porcelæn, kosmetik, cigaretter, hårbalsam og biodiesel. Med en kirurgisk teknik bliver svinet gennemdissekeret, hvor slutproduktet gengives i fuld skala. "Vores liv bliver bedre, hvis vi kender sammenhængen mellem de produkter, vi forbruger, og de materialer, de er lavet af. Jeg tror, at bare en smule interesse vil være et stort skridt i retning af at tage vare på denne arv." 25

Den måde, Meindertsma gør svinet til indeks, er at anskue det $i$ en sammenhæng og se de enkelte dele som en del af svinets fortælling. ${ }^{26}$ På samme måde med en tekst. Også den kan danne indeks efter brug. Man kan opfatte hele Gammel Testamente, eller dele af det, som et indeks: Det kunne gælde for loven, toraen. Vi ved, at den er en del af Mosebøgerne. Vi ved, at den kan fungere som lovgivning. Vi ved også, at den er fyldt med en lærdom, som skal anvendes i familien som opdragelse. Og vi ved, at toraen også er ensbetydende med visdom, som det kan komme til udtryk i salmerne. Den ene tolkning og forståelse udelukker ikke den anden, i den forstand er toraen et indeks.

Et andet eksempel kunne være en bibelsk figur. Der er kun få spor tilbage af erindringen om Mirjam. Den dukker op her og der i de bibelske tekster, og Mirjam omtales i andre antikke tekster, som fx hos Josefus. Qumranteksterne erindrer Mirjam, og der er også spor gemt i stednavne ved Petra, Geneserats sø fx. Ingen kan huske helheden,

23. Haakon Lund. Danmarks Havekunst III, 2000, 359.

24. Viggo Nielsen, "Academia Peripathetica. Den historiske rundgang i Lejre", Architectura 12 (1990), 36-68 (38).

25. http://www.we-make-money-not-art.com/archives/2008/08/christien-meindertsma-what-is.php

26. http://www.joliat.net/pig05049.html 
og ingen kan rekonstruere en historisk sammenhæng på baggrund af sporene. ${ }^{27}$ Det er ikke muligt, fordi de enkelte erindringer ikke hænger sammen. Gammel Testamente danner indeks og kan indgå i den kulturelle erindring på mange måder. Det, den kulturelle erindringsforskning undersøger, er, som sagt indledningsvis, ikke oprindelse, men hvordan fortiden er blevet fortalt, hvordan erindringen er blevet formidlet og cirkuleret, den fokuserer på, hvordan erindringen fungerer. Mirjam er med Noras ord et "lieu de mémoire", ${ }^{28}$ et sted for erindring, en figur der tiltrækker erindring, og som dermed lever videre. For erindring er forvaltning af fortiden $\mathrm{i}$ nutiden, og uden fortiden er det ikke muligt at forestille sig fremtiden. I kraft af sin forestillingsevne er mennesket $\mathrm{i}$ stand til at foretage tidsrejser. Det er en måde at leve aktivt med en erindring, der gør det muligt for mennesket at orientere sig. ${ }^{29}$ Hvad angår erindringen om Mirjam, så findes der ikke længere en kontekst eller et reelt miljø for den. ${ }^{30}$ Derimod er erindringen blevet genskrevet, og Miriam er blevet en palimpsest. Dermed har Mirjamskikkelsen ved dette genbrug og denne overskrivning levet videre, også uden for sin bibelske sammenhæng. Mirjam er et indeks, hvor der er glemte og uforståelige elementer gemt, som i dag danner nye kontekster og forståelser. ${ }^{31}$ Det klassiske eksempel på et indeks er, at "røg" indekserer ild, ild forårsager røg. Et andet kendt eksempel er, at et smil er et indeks for en venlig holdning. Men vi ved jo, at røg kan opstå uden ild, og et smil kan skyldes ren og skær konvention (Gell 1998, 13).

Erindringen om Mirjam kan være et indeks for "ledelse" (Num 12,2 og Mika 6,4), "helbredelse" (legenden om Mirjams kilde), "profetiske evner" (Ex 15,20), “identitet” (en central figur i ørkenvandringen), "geografi" (knyttet til ørkenvandringen, Geneserats sø, Petra), "spedalsk" (Num 12) og "søsterskab" (Ex 15,20). Det bærende for en

27. Max Saunders, "Life-Writing, Cultural Memory, and Literary Studies", i: Erll 2010, 322.

28. Pierre Nora, Between Memory and History: Les Lieux de Mémorie”, Representations 26, 1989, (7-24, 8).

29. Thomas Suddendorf and Michael C. Corballis, "Mental time travel and the evolution of the human mind", Genetic, Social and General Psychology Monographs, 123, 1997, 133-167; Thomas Suddendorf og Michael C. Corballis, "The evolution of foresight: What is mental time travel, and is it unique to humans", Behavioral and Brains Sciences 30, 2007, 299-351.

30. Pernille Carstens, "Mirjams hemmelighed - den som ikke kan huske, har ikke noget at fortælle", Bibelske genskrivninger, Forum for Bibelsk Eksegese 17, red. Jesper Høgenhaven og Mogens Müller (København 2012: Museum Tusculanum), 341-361.

31. Alfred Gell, Art and Agency. An Anthropological Theory (Oxford: Clarendon Press 1998). Se for en udfoldelse Andrew Jones, Memory and Material Culture (Cambridge: Cambridge University Press 2007), 18ff. 
forståelse af, hvilke elementer, der har overlevet, hvilke spor der blev bevaret, er konteksten for traditionen eller erindringen. ${ }^{32}$ Der er altid brugere eller agenter forbundet med et indeks, og det at glemme og at huske er en aktiv og vedvarende proces. Man kunne spørge, hvorfor de forskellige spor om Mirjam findes i Det Gamle Testamente eller det ekstrabibelske materiale. Hvem er brugerne af Mirjam-traditionen, og hvilken social sammenhæng indgår de i?

\section{Erindringens betydning for at skabe håb}

For at fastholde eksemplet med Mirjam så viser det, at erindringen er af betydning for at skabe et håb, ikke kun internt i en gammeltestamentlig sammenhæng, men mindet om Mirjam findes fortsat, som jeg viser i citatet nedenfor. At fortælle Mirjams historie kan have stor betydning for tilblivelsen af det jødiske folk, for erindringen om hende gemmer på afgørende træk fra ørkenvandringen. Den er en afgørende og formativ periode i folkets historie. At fornægte erindringen om hende ville være at undgå at følge afgørende spor. ${ }^{33}$ Formålet med at fastholde et specifikt minde kan skyldes ønsket om at beskytte sig selv. Livshistorien er med til at organisere erindringen som autobiografisk og skabe en sammenhængende fortælling. Livshistorie eller autobiografisk erindring er et vigtigt redskab i moderne terapi: "Du er, hvad du erindrer", og det er muligt at skabe en livshistorie og dermed komme i kontakt med sig selv. "Getting a life" făr man ved at fortælle sin livshistorie, og autobiografien kan placeres på et så generelt niveau: Gennem en livshistorie eller biografi kan den store fundamentale fortælling om et folk blive fortalt, sådan som det sker med Mirjams erindring. Mirjam spiller en central rolle i udfrielseshistorien i Israel. Hun er søster til Moses og fra første færd forbundet

32. Spor fremhæves meget konkret af Andrew Jones 2007, 22-26. Hundespor på stien indicerer, der har gået en hund der før os, i fortiden. Vi kan ikke se hunden, men vi kan abducere os frem, for vi ved, hvordan det er at gå med en hund selv, og vi kender udseendet af dens spor. Det er således den almenmenneskelige erfaring, der gør dette muligt for os.

33. En af de vigtigste artikler i forskningen af livshistoriens betydning for selvet er Tilmann Habermas and Susan Bluck, "Getting a Life: The Emergence of the Life Story in Adolescence", Psychological Bulletin 126, 2000, 748-769. Se også David C. Rubin (ed.), Remembering our Past. Studies in Autobiographical Memory. (Cambridge: Cambridge University Press 2005). W.R. Mackavey, J.E. Malley,og A.J. Stewart, "Remembering autobiographically consequential experiences: Content analysis of psychologists' accounts of their lives", Psychology and Aging 6, 1991, 5059. D.P. McAdams, "The Psychology of Life Stories", Review of General Psychology 5, 2001, 100-122. Max Saunders, "Life-Writing, Cultural Memory, and Literary Studies", i: Erll 2010, 321-333. 
med ham i forbindelse med episoden på Nilen, hvor Moses sættes ud (Ex 2). Hun synger sin sejrssang (Ex 15), da folket krydser Sivhavet og hylder sin brors handlinger. Det meste af sit liv lever hun i ørkenen, hun er knyttet til kilden (Num 20,2-13 og i legendestoffet) og følger folket på vandringen. Hun spiller en rolle i lovdidaktikken $\mathrm{i}$ Deut 24, da hendes sygdomsangreb, som det fortælles om i Num 12, anvendes i opdragelsesøjemed (Carstens 2012, 352).

Hun er begravet tæt på Petra, som man læser hos Josefus, og hendes kilde fortsætter sin aktivitet derefter ved Geneserat sø og helbreder fortsat (Carstens 2012, 250f.).

Erindringen om Mirjam er knyttet til fortællinger og legender om det levende vand. Mirjam bliver husket, fordi hun er en karismatisk figur, og omkring sådanne knyttes ofte mange minder. Hun er det vand, der vælder frem i ørkenen; dér hvor man forventer tørke, giver hun liv (Es 35,6). Mindet om hende er derfor vigtigt, når der skal skabes national identitet, og det er muligvis derfor, hun i dag spiller en rolle i et nyt moderne jødisk ritual. Det er et feministisk ritual, der indgår i organisationen Mirjams kilde (Carstens 2012:357). Ritualet skal foregå i påsken, hvor Mirjams kop sendes rundt, og man mindes, hvordan Mirjam sørgede for den levende kilde til folket under ørkenvandringen. Ved denne kilde kan man helbredes, og hendes mod styrkede folket på vandring. Ritualteksten fortsætter med at knytte bånd mellem fortid og nutid og give håb for fremtiden:

We fill Miriam's cup with water to honor her role in ensuring the survival of the Jewish people. Like Miriam, Jewish women in all generations have been essential for the continuity of our people. As keepers of traditions in the home, women passed down songs and stories, rituals and recipes, from mother to daughter, from generation to generation. Let us each fill the cup of Miriam with water from our own glasses, so that our daughters may continue to draw from the strength and wisdom of our heritage. ${ }^{34}$

34. http://www.miriamscup.com/RitualFirst.htm 